\title{
An Analysis on the Overseas Investment Strategy of Chinese Real Estate Enterprises
}

\author{
Li-ming $\mathrm{HONG}^{\mathrm{a}, \star}$, Yu-ting DU ${ }^{\mathrm{b}}$ \\ School of Economics and Management, Xiamen University of Technology \\ Xiamen, China

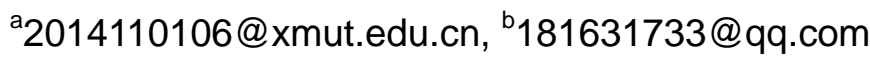 \\ ${ }^{*}$ Corresponding author
}

Keywords: Real Estate Enterprises; Overseas Investment; SWOT.

\begin{abstract}
The rapid development of the real estate market in China has resulted in many powerful real estate enterprises, whereas become increasingly saturated. It is urgent to open up the international market while opportunities and challenges coexist in the globalization process of real estate enterprises. Furthermore Chinese real estate enterprises lack experience in international investment, and it is of great practical significance to formulate a reasonable overseas investment strategy. This paper introduces the current situation of foreign investment in Chinese real estate enterprises, and applies SWOT analysis to carry out research on the overseas investment strategy of real estate enterprises in China, which will inspire and help many of the real estate enterprises in China to growth continuous and healthy.
\end{abstract}

\section{Introduction}

In the past decade or so, Chinese real estate market has grown rapidly with the particularity compared with other countries. First, it is extremely sensitive to domestic real estate registration policies and highly depends on banks. The price of real estate fell by $7 \%$ in 2014 for the real estate registration policy, and the prices in some cities even have dropped by $50 \%$ since 2018 due to the strict domestic real estate control policies [8]. Secondly, the consumption cycle is long and the land use right of residential real estate reaches 70 years. Finally, the public's psychological needs are more obvious. The Chinese people have the concept of home ownership since ancient times and the domestic demand is relatively large.

With the gradual saturation of the domestic real estate market, an increasing number of large real estate companies turn to overseas investment to seek new profit points. The total overseas real estate investment of China increased from 33 million US dollars to 600 billion US dollars from 2009 to 2015 under the Chinese foreign investment market report published by Cushman \& Wakefield.

In terms of the distribution of overseas investment areas, the real estate enterprises of China mainly invest in developed countries and its surrounding countries and regions [2]. The proportion of investment in the United States was $21.4 \%$, followed by the United Kingdom 9.8\%, Malaysia 7.6\%, South Korea 7.6\%, Nigeria 6.6\%, Germany 5.6\% and North Korea 5.3\% in 2015 [1]. The Chinese enterprises invest in overseas office buildings, land development, hotels and retail real estate, in which the buildings and land development are the main components. The investment amount of office buildings, land development, hotels and retail real estate accounted for $40 \%, 33 \%$, $14 \%$ and $10 \%$ of the total foreign investment respectively in 2015 [1]. The oversea investment enterprises include state-owned real estate enterprises, large-scale listed real estate development enterprises and insurance companies in China. In 2015 the amount of overseas investment by state-owned real estate companies in China accounted for $58 \%$ of the total amount. Greenland Group as the main state-owned enterprise invested the real estate in South Korea, the United States, Australia and other countries, with a total of 3.6 billion US dollars from 2012 to 2013, and the overseas investment of listed real estate companies and insurance companies accounted for $20 \%$ and $18 \%$ of the total investment respectively [1]. 


\section{SWOT Analysis of Chinese Real Estate Enterprises to Overseas Investment}

The SWOT model comprehensively studies the internal and external conditions for enterprises involving the overseas investment, including the advantages and disadvantages of enterprises, as well as the opportunities and threats that may be faced. Therefore it helps make development strategy of the enterprise, give full play to the advantages of the real estate enterprise and avoid disadvantages.

\section{Advantages of Chinese real estate enterprises to overseas investment}

Domestic real estate enterprises have abundant funds and rich experiences in development and management. The rapid development of domestic real estate market in the past decade has prompted the growth of a large number of large-scale and capable real estate companies. According to the China Real Estate Index System (CREIS) survey data, there were 7 companies with a total sales volume of over 100 billion in 2014, in which the total sales of both China Greenland and Vanke exceeded 200 billion yuan.

The rich experience of other industries can be used as a reference. In some mature industries of China such as household appliances, energy development and utilization, non-ferrous minerals and other mature industries, the companies have carried out overseas investment business very early. They have laid a full-scale empirical foundation for overseas investment in the real estate industry including capital operation, M\&A and legal systems, and accumulated more valuable experience for the smooth development of overseas investment by domestic real estate enterprises.

More and more domestic in-house operators turn their attention to foreign countries. Chinese real estate enterprises are familiar with the preferences of domestic overseas home buyers, which can provide an indispensable sales channel for their overseas real estate investment.

The appreciation of the RMB for more than a decade has increased the international purchasing power helping Chinese real estate companies purchase higher-value overseas real estate with less capital and promoting the overseas investment.

\section{Disadvantages of Chinese real estate enterprises to overseas investment}

There are indelible cultural differences between the investment and host countries. The design of real estate products should follow the needs of the customer groups, but the foreign customer groups with different cultural backgrounds have great conflicts in the real estate product characteristics.

Overseas real estate investment is concentrated excessively in developed countries such as the United States, the United Kingdom and Germany. Although these regions have mature market systems and open trade markets, the markets of developed countries are already saturated with high threshold for investment. Moreover, excessive concentration could limit the internationalization of domestic companies.

There is a serious shortage of international talents. Although domestic real estate enterprises have cultivated many talents to adapt to the domestic market, they lack talents for the international market. It is urgent to cultivate compound international talents.

The Chinese companies lack international recognition. Chinese large real estate enterprises have high domestic reputation, but cannot compete with local companies for overseas consumers. The non-international brands have hindered the oversea investment of domestic real estate enterprises.

\section{Opportunities for Chinese real estate enterprises to investment overseas}

"One Belt, One Road" initiative of China has enhanced the confidence of Chinese real estate enterprises in foreign investment, and promulgated a number of policies and regulations to provide a strong guarantee for domestic enterprises to successfully carry out overseas investment $[3,4]$.

The stable host country market provides an important opportunity for Chinese real estate investment and obtains a return on investment [5]. For example, affected by the 2008 financial crisis, the Australia market has grown steadily for nearly two decades and attracted many Chinese real estate companies.

The better real estate policy in the host country is also important. Compared with the current 
domestic real estate market under strict regulation, foreign markets are more relaxed. Many foreign governments have different preferential policies for home buyers such as Australia and the United Kingdom, their property rights are permanent and the land belongs to individuals. This attracts domestic customers to make immigration decisions.

Host countries affected by the financial crisis encourage foreign investment capital to inject vitality into the local economy such as Europe under sovereign debt crisis, bringing opportunities for Chinese enterprises to overseas investment. Jeju Island government implemented a policy that foreign buyers who invested $\$ 500,000$ in the local area could obtain permanent residency in 2010 , and attracted Greenland Group to develop a tourism health city project in Jeju Island in 2011.

There are cultural similarities between China and neighboring countries, such as collectivism, large power distance, masculinity and low degree of uncertainty avoidance, therefore the surrounding countries such as Thailand, Singapore, Malaysia, etc. have become the preferred destination for overseas investment in China.

\section{The threats for Chinese real estate enterprises to investment overseas}

The fluctuation of RMB exchange rate could lead to the loss of the oversea real estate of the Chinese company.

Local real estate companies are the biggest competitors. It is easier for local real estate companies to master their own economy, culture, and laws to meet customer needs, and to obtain support from local governments and related equipment, which has become a dilemma for Chinese companies to enter foreign markets.

International investment restrictions of host government have a great influence. In order to protect domestic real estate enterprises and prevent excessive housing prices, some countries have introduced various policies to limit foreign capital investment in domestic real estate. For example, New Zealand banned overseas buyers from buying domestic property in 2018, and Australians ban overseas buyers to buy second-hand houses [5].

\section{Conclusions}

Chinese real estate enterprises could adopt the following development strategies to prompt their overseas investment according to SWOT analysis above.

Growth strategy: give full play to the advantages and seize the opportunity of opportunity. The Chinese real estate enterprises should make full use of the policy support under the "Belt and Road Initiative" to explore and meet the consumer demand of domestic overseas home buyers, learn from the successful experience of overseas investment in other industries and domestic estate investment, and invest in host countries which have quality real estate development policies, good economic development potential or high cultural similarity.

Reversed strategy: reverse the disadvantages and take advantage of opportunities. Cultivate and introduce international talents, especially local employees who are familiar with the market environment of the host country, and thus receive support from the host government [7]; cooperate with professional real estate agencies in the host country and pay attention to the different needs of real estate in different countries.

Diversified business strategies: give play to strengths and eliminate threats. Use stable currency or financial instrument transactions, or eliminate foreign exchange risk through long-term foreign exchange transactions, bank factoring and other financial instruments; enhance brand image and cooperate with professional real estate intermediary in host countries; implement market diversification strategy, learn advanced management experience and technology from advanced countries, give full play our own financial advantages and rationally adjust market strategies to balance the risks of domestic real estate development.

\section{Acknowledgement}

This research was financially supported by Social Science Planning Project in Fujian Province of 
China (Funding No. FJ2016C132).

\section{References}

[1] 2015 Chinese foreign investment market report published by Cushman wakefield. Information on http://www.cushmanwakefield.com.cn/.

[2] Y. Zhou, He Lunzhi. Current Status, Risks and Avoidance Measures of Overseas Real Estate Investment in China's Housing Enterprises [J]. Practice in Foreign Trade and Economics, 2016, (07): 82-85. (in Chinese)

[3] Y. Xuebo, Research on the influencing factors and strategies of foreign direct investment in Chinese real estate enterprises [D]. Southeast University, 2015. (in Chinese)

[4] W. Ping, Opportunities and Challenges of China's Foreign Direct Investment in the Background of the "Belt and Road" [J]. Contemporary Economy, 2017, (20): 11-13. (in Chinese)

[5] F. Yangyang, Research on overseas mergers and acquisitions of Chinese real estate enterprises [D]. Henan University, 2014. (in Chinese)

[6] W. Xuexiao. Research on Competitive Strategy of Real Estate Development Enterprises [D]. Beijing Jiaotong University, 2004. (in Chinese)

[7] Z. Yongchuan. Research on the development strategy of overseas investment of real estate enterprises in China [D]. Yunnan University, 2015. (in Chinese)

[8] Information on http://www.stats.gov.cn/ 